\title{
Strengths-based approaches to disability, the supports paradigm, and the importance of the supports intensity scales
}

Abordagens baseadas em potencialidades para a deficiência, paradigma de suporte e a importância das escalas de intensidade de suporte

Enfoques de la discapacidad basados en potencialidades, el paradigma de los apoyos y la importancia de las escalas de intensidad de los apoyos

\section{Michael Wehmeyer}

Ph.D. distinguished professor at the University of Kansas, Lawrence, Kansas, United States of America. wehmeyer@ku.edu

ORCID - http://orcid.org/0000-0001-9220-7508

Recebido em 20 de julho de 2020

Aprovado em 6 de agosto de 2020

Publicado em 17 de novembro de 2020

\section{ABSTRACT}

Historically, disability has been conceptualized within deficits-based models. But, newer models that emphasize the fit between health, the environment, and personal factors are leading to strengths-based approaches to supporting people with disabilities. This article explores implications for such models on disability, in general, and special education, specifically. The importance of self-determination to operationalizing such models is discussed. Finally, the shift to a supports paradigm as part of the response to personenvironment fit models is examined, along with a discussion pertaining to a series of measures of support needs.

Keywords: Strengths-based approaches; self-determination; Supports Intensity Scales.

\section{RESUMO}

Historicamente, a deficiência foi conceituada em modelos baseados em déficits. Contudo, modelos mais recentes que enfatizam a adequação entre saúde, meio ambiente e fatores pessoais estão levando a abordagens de potencialidades para apoiar as pessoas com deficiências. Este artigo explora implicações para esses modelos sobre deficiência na educação regular e, especificamente, na educação especial. A importância da autodeterminação para operacionalizar esses modelos é discutida. Finalmente, é examinada a mudança para um paradigma de suporte como parte da resposta aos modelos de ajuste pessoa-ambiente, juntamente com uma discussão referente a uma série de medidas de necessidades de suporte.

Palavras-chave: Abordagens baseadas em potencialidades; autodeterminação; Escalas de Intensidade de Suporte.

\section{RESUMEN}

Históricamente, la discapacidad ha sido conceptualizada dentro de modelos basados en déficit. Pero, los modelos más nuevos que enfatizan el ajuste entre la salud, el medio ambiente y los factores personales están conduciendo a enfoques basados en potencialidades para apoyar a 
las personas con discapacidad. Este artículo explora las implicaciones para tales modelos sobre discapacidad, en general, y educación especial, específicamente. Se discute la importancia de la autodeterminación para poner en práctica dichos modelos. Finalmente, se examina el cambio a un paradigma de apoyos como parte de la respuesta a los modelos de ajuste persona-ambiente, junto con una discusión relacionada con una serie de medidas de necesidades de apoyo.

Palabras clave: Enfoques basados potencialidades; autodeterminación, Escalas de Intensidade de Apoyo.

\section{Introduction}

The standard for how people with disability should be treated has been set forth in the United Nations Convention on the Rights of Persons with Disabilities. Those standards, as articulated in the General Principles of the CRPD, are of "respect for inherent dignity, individual autonomy including the freedom to make one's own choices, and the independence of persons." In Article 24 of the CRPD, pertaining to education and to the focus of this conference on inclusive education, the CRPD states that parties who adopt the CRPD "shall ensure an inclusive education system at all levels and lifelong learning directed to: "shall ensure an inclusive education system at all levels and lifelong learning directed to: a) the full development of human potential and sense of dignity and self-worth, and the strengthening of respect for human rights, fundamental freedoms and human diversity; b) the development by persons with disabilities of their personality, talents and creativity, as well as their mental and physical abilities, to their fullest potential; c) Enabling persons with disabilities to participate effectively in a free Society" (COMMITTEE ON THE RIGHTS OF PERSONS WITH DISABILITIES, 2016, Art. 24).

It is clear, then, that issues of special education are linked to themes of dignity, autonomy, self-worth, choice, and participation (WEHMEYER, 2019). Yet, if we examine how people with disability have been treated, historically, these themes are far too often absent. Indeed, one can easily argue that the opposite of dignity-indignity-is the state that most people with disability experience (SMITH; WEHMEYER, 2012; WEHMEYER, 2013a). This is, I believe, in large measure a function of how we have understood the construct of disability over time. Historically, disability was understood within a model that was an extension of a medical model that conceived health problems, including disability, as an individual pathology. Disability was understood to be a characteristic of the person; as residing within the person and that person was seen as broken, diseased, pathological, 
http://dx.doi.org/10.5902/1984686X48249

atypical, or aberrant; as outside the norm. Not surprisingly, such attributions led mainly to segregation, and disability was associated with negative societal outcomes and people with disabilities viewed as social problems (SMITH; WEHMEYER, 2012).

As the 20th Century progressed, traditional conceptualizations of disability began to be replaced by ways of thinking about disability that focused more on the interaction between personal capacity and the context in which people with disabilities lived, learned, worked, and played (WEHMEYER, 2013b). Particularly, two World Health Organization taxonomies of disability emerged that provided us with a language to begin talking about strengths-based and positive approaches to disability.

\section{Changing Understandings of Disability}

The first taxonomy introduced by the WHO was the International Classification of Impairments, Disabilities, and Handicaps, or ICIDH, introduced in 1980. What had become apparent by then was that thinking about chronic or long-term health issues, like disability, solely within a pathology model was no longer helpful. The ICIDH was intended not as a classification of diseases or disorders for diagnostic purposes, as prior WHO classification systems were intended, but instead as a means to classify the consequences of disease, injuries, and other disorders and of their implications for the lives of the person experiencing these. The ICIDH recognized that disability was not simply a function of health problems, but instead was a function of health-related issues and their interaction with the context and the person. The ICIDH was a first step in 'externalizing' disability; by that I mean that it was a first step in moving the understanding of disability from an internal pathology or a characteristic of the person, to being a result of the interaction between health, environment, and personal factors (BUNTINX, 2013).

In 2001, the WHO introduced the International Classification of Functioning, Disability, and Health, or ICF, which extended this understanding to conceptualize disability as a function of health, environmental, and personal factors and, importantly, conceptualized disability as a part of, and not apart from, typical human functioning (BUNTINX, 2013).

Let me summarize what I think the WHO classifications established in a more simplistic way. The focus of these new models of disability termed social-ecological or personenvironment fit models, shifted from an emphasis on disability as deficits and disability as residing within the person to a focus on the fit between a person's capacities, their strengths, and the demands of the context in which he or she might live, learn, work or play. Disability 
http://dx.doi.org/10.5902/1984686X48249

resides only in this gap, and the degree to which we can reduce the gap between a person's capacity and the demands of the environment, then although the impairment that resulted in disability doesn't go away, the disability becomes, in essence, irrelevant.

\section{Implications for Person-Environment Fit Models in Disability Supports}

There are multiple implications of conceptualizing disability as a function of the fit between the demands of the environment and the person's capacities that can guide our efforts to achieve the vision of the parent movement. First, this is a strengths-based approach to disability. In 2013, I edited the Oxford Handbook of Positive Psychology and Disability (WEHMEYER, 2013b), a book that I would not have been able to edit ten years before that because we lacked the language and frameworks within which to talk about the strengths of people with disabilities. Second, these person-environment fit models emphasize disability within the context of typical human functioning, and not in some way apart from the typical human experience. The focus of action as a function of such models is on the identification and design of supports to address the person's participation within typical contexts.

\section{Implications for Person-Environment Fit Models for Special Education}

The good news for those of us in the field of special education is that we don't have to start from scratch with the design of interventions that are driven by person-environment fit models of disability. There are, in fact, multiple examples from emerging best and effective practices in the education of learners experiencing a disability that illustrate the application of this new disability paradigm to educational practice and that, in turn, promote greater inclusion. These include the implementation of Universal Design for Learning and the use of technology to promote greater access to curricular materials; schoolwide applications like Positive Behavior Intervention and Supports and Multitiered Systems of Supports; the application of a personalizable education; a focus on self-determination and self-determined learning, and active student involvement and engagement in educational planning (WEHMEYER, 2019).

All of these take approaches consistent with person-environment fit models of disability by focusing as much on changing the environment and the context and providing supports as on changing the person (THOMPSON; WEHMEYER; HUGHES, 2010). For example, positive behavior interventions and supports involve changing or modifying the environment 
http://dx.doi.org/10.5902/1984686X48249

or context so that problem behavior is no longer necessary and then providing instruction on more social-acceptable ways to achieve one's goal or purpose (SHOGREN; WEHMEYER; LANE, 2016).

Or, consider at how principles of Universal Design for Learning operationalizes personenvironment fit models. These principles emerged fom the field of architecture and suggested that all buildings/environments should be designed to be accessible to all people without the need for modification or adaptation by incorporating ramps, wide doors, or accessible restrooms (ROSE et al., 2002).

Education policymakers, throughout the world, adopted this approach to supporting students to gain access to the general education curriculum. The "universal" in universal design does not imply one optimal solution for everyone, but rather it underscores the need for inherently flexible, customizable content, assignments, and activities. My favorite definition of UDL defines it as "the design of instructional materials and activities that allows learning goals to be achievable by students with wide differences in their abilities to see, hear, speak, move, read, write, understand [English], attend, organize, engage, and remember" (ORKWIS; MCLANE, 1998, p. 9). I don't know too many students, with or without a disability, who aren't described to some degree by this list! And, back to my main point, UDL is all about changing the context or the environment (in this case, the curriculum) to be usable by everyone, as suggested by person-environment fit models.

We tend to equate UDL with technology, and although there are ways to ensure universal access to educational content that does not use technology, it is a fact that there are a myriad of barriers to full participation that will be removed by technology in education and other life domains (WEHMEYER et al., 2012b). Digital talking books, smartphones, and tablets provide platforms for universally designed learning materials to be presented. The growth of cloud based technologies will soon make the specific device you use irrelevant, as all personalization features will reside in the cloud and you will be able to access them anywhere, with any type of device. 3D printing will, over the next decades, change the face of manufacturing. Instead of buying mass-produced products that do not fit their needs, 3-D printing will allow people with disabilities to manufacture exactly what they need to be supported to do what they want. Finally, you may have heard the term "the Internet of Things" or the "Internet of Everything" (WEHMEYER, 2019). This is the idea that someday, and that day will be sooner rather than later, everyday objects, people, processes, and data will be networked and connected such that what you cannot do will be irrelevant; what will 
http://dx.doi.org/10.5902/1984686X48249

matter will be the supports available for you to succeed. Right now, about 7 billion objects are connected to the internet; by 2025 , that figure is estimated to be almost 25 billion objects (EVANS, 2011). If you can't drive, it won't matter, cars will drive themselves; Google glass and Apple watch are only the tip of the iceberg for wearable computing.

Finally, before talking more extensively about the role of supports and the supports intensity scales, it is important to note the critical role that promoting self-determination plays in operationalizing person-environment fit models of disability and in ensuring that students with disabilities are successful in 21st Century schools.

A world class education, according to Yong Zhao in his book World Class Learners: Educating Creative and Entrepreneurial Students (2012), is characterized by student voice in school governance and environment, student choice in a broad and flexible curriculum, and a strengths-based focus on student uniqueness and curiosity. Zhao notes that because of increased human productivity and the rapid rise of technology, people spend much less of their annual income on necessities like food, clothing, and shelter and substantially more (in fact, more than twice what was the case in the 20th Century) on everything else. While traditional jobs may be lost in a global, technological economy, jobs will be gained in other largely unidentified domains. As a result, more and more talents and abilities will have economic importance. He noted:

Today, in the new age, a majority of traditional routine tasks that required a homogenous set of skills and knowledge are now performed by machines, and human needs have shifted from basic needs to more psychological, aesthetic and intellectual needs. Thus, the full spectrum of human talents has become economically valuable (ZHAO, 2012, p. 57).

And, at the heart of these innovations in education are student agency and selfdetermination. It is clear that to prepare young people for the 21 st Century world, among the most important things we can do is to presume that students are capable of being successful, promote self-determination and student involvement, emphasize goal setting and problem solving, and consider student strengths and support students to design a life based on those strengths, interests, and abilities (WEHMEYER; ZHAO, 2020). As a field, we have compelling evidence of the positive impact on promoting self-determination on students with disabilities on more positive school and adult outcomes (SHOGREN et al., 2012; WEHMEYER et al., 2012a; SHOGREN et al., 2015; WEHMEYER, 2019). It is clear that if we are to fulfill the vision of the CRPD, an important part will be by promoting selfdetermination. 
http://dx.doi.org/10.5902/1984686X48249

\section{Supports, Support Needs, and The Supports Intensity Scale Measures}

Turning now to the importance of a supports focus in person-environment fit models and strengths-based approaches. Both of these focus on the importance of supports to improve the fit between the person's strengths and the demands of the context (THOMPSON; WEHMEYER; HUGHES, 2010). Supports are "resources and strategies that aim to promote the development, education, interests, and personal well-being of a person and that enhance individual functioning" (LUCKASSON et al., 2002, p. 151). Resources and strategies are anything, really, that enable people to function successfully, from technology to services to relationships. Support needs refer to "a psychological construct referring to the pattern and intensity of supports necessary for a person to participate in activities linked with normative human functioning" (THOMPSON et al., 2009, p.135). That enable, I would argue, people to live self-determined lives. Further, supports "refer to an array, not a continuum, of services, individuals, and settings that match the person's needs" where the person is in the center, and types of supports radiate out from self-directed and selfmediated supports, to supports from the person's family and friends and non-paid supports, like coworkers or neighbors, to generic supports (those that everyone uses) and specialized supports, like those provided in a disability service system.

It is important to recognize that there are multiple influences on the support needs of people with intellectual disability. One of these influences is level of personal competence, what people can do well. It is likely that the greater an individual's level of personal competence, the less the intensity of support needs. Conversely, likely the lower a person's level of personal competence, the greater the support needs. Thus, education plays a critical role in enhancing personal competence and, as such, improving the fit between what a person can do and what that person wants to do by providing the knowledge and skills they need to function more successfully.

But a focus only on personal competence misses the fact that there are many other factors that influence support needs. Among these are exceptional medical support needs (the greater the medical needs the greater the support needs), exceptional behavior support needs (again, the greater the behavioral considerations, the greater the support needs); the number and complexity of the settings in which a person participates (the more complex, the greater the support needs - moving about a small town requires less support than moving around a large city); and the number and complexity of the life activities in which an person participates (e.g., the more complex the job, the greater the need for support). 
http://dx.doi.org/10.5902/1984686X48249

Inferring a person's pattern and intensity of support needs from traditional measures of personal competence (or incompetence) is unlikely to result in less useful information because such measures, like IQ scores and adaptive behavior measures, do not provide a complete measure of personal competence, nor do they account for the other influences on support needs.

As a means to move the field from a focus on deficits and disorders and as a means to provide a means to measure support needs, a number of us involved in the American Association on Intellectual and Developmental Disabilities (AAIDD) were tasked with developing an assessment of support needs for people with intellectual disability (THOMPSON et al., 2004). We operated under two assumptions: people with intellectual disability are different from the general population because they require more and different types of support to fully participate in the activities of daily life and that understanding people by their support needs is more functional (i.e., useful) for purposes of planning than understanding their deficits or the etiology of the disability.

Those of us tasked with developing a measure to operationalize changing ways of conceptualizing disability have, over time, created a suite of standardized assessment tools specifically designed to measure the pattern (e.g., the regular and consistent way in which people need support) and the intensity of supports needed by an children, youth, or adults with intellectual and developmental disabilities. These Support Intensity Scales (or SIS) move the field away from measures of incompetence or indirect indicators of support needs, and focus on what supports are needed for the individual to be successful in typical environments. The SIS has been validated in Brazil (ALMEIDA; BOUERI; POSTALLI, 2016). The SIS tools are intended to assist planning teams in making clinical judgments regarding a person's support needs. The SIS tools are not diagnostic tools (i.e., does not diagnose intellectual disability). In 2004, we published the original Supports Intensity Scale. It was the first standardized measure of support needs and was validated with adolescents and adults ages 16 to 64 . The SIS became widely adopted nationally and internationally for resource allocation and supports planning (see https://www.aaidd.org/sis/international). In 2015, we published a 'refreshed version' of the SIS, now referred to as the Supports Intensity ScaleAdult version, or SIS-A. The following year, in 2016, a Children's version of the SIS was published (THOMPSON et al. 2016a), which was the first standardized measure of support needs for children ages 5 to 16. The following year, we published a SIS-A annual review protocol (THOMPSON et al., 2017), which provides professionals with a means to determine 
http://dx.doi.org/10.5902/1984686X48249

if there is a need to perform a full SIS-A assessment. Finally, most recently, we published a guide to person-centered planning using the SIS-A (THOMPSON et al., 2016b). This suite of tools provides a comprehensive way to assess support needs and design supports.

Both the SIS-A and the SIS-C are administered and scored in identical ways. An interviewer, who is a person, including a teacher, with training and experience in assessing people with intellectual disability, must interview and at least two respondents who know the person who is being assessed well. The interviewer must probe and make scoring judgments if respondents disagree. These interviews can be one-on-one, or in groups. Respondents provide their assessment of the frequency, daily support time, and type of support needed for the person to perform successfully in typical contexts. When a person is not currently performing an activity, clinical judgment must be used in estimating support needs, but ratings should reflect the supports that would be necessary for this person to be successful in each activity. A description of the instruments and items can be found at https://www.aaidd.org/sis/product-information. Each item makes an assumption that the person has the opportunity to participate at levels potentially requiring maximum frequency, time, and type of support. Therefore, respondents should remember that ratings can reflect this maximum level of potential activity.

The SIS measures yield two indicators of support needs: first, is the Support Needs Index (SNI), which is a norm referenced support needs score (based upon responses to each of the items in the measure) that provides an indication of a person's intensity of support needs relative to other people with intellectual disability. The mean on the SNI is 100 and the Standard Deviation is 15. Higher scores mean greater support needs, lower scores mean less support needs. Thus, a person with an SIS Support Needs Index Score of 70 would be 2 SD below the mean in terms of support needs, and therefore require less support than $98 \%$ of the standardization sample. Second, the SIS results in a support needs profile, which summarizes a person's relative intensity of needed support across different life areas (Home Living Activities, Community Living Activities, Lifelong Learning Activities, Employment Activities, Health and Safety, and Social Activities). The different areas on the support needs profile are measured by the subscales on the SIS, and therefore enables consideration of the pattern of an individual's support needs. A person may have relatively less support needs in one area versus another.

Because we are focused on special education, the remainder of this discussion will focus on the Supports Intensity Scale - Children's Version, called the SIS-C (see 
http://dx.doi.org/10.5902/1984686X48249

https://www.aaidd.org/sis/sis-c for details). The SIS-C was developed using the same general measurement framework, rating system, and several common support need domains as were presented in the SIS-A. It has two sections: Exceptional Medical and Behavioral Needs and the Support Needs Scale. There is close alignment between support needs domains in the SIS-A and the SIS-C, including parallel constructs that are common across the two measures. But, there are also domains that are unique to children's support needs that are not parallel to domains in the SIS-A, such as school-related activities.

The response scale for the SIS-C also closely resembles the SIS-A, with some adjustments. The Type of Support response scales and the Daily Support Time response scales are identical between the two measures. The Frequency of Support ratings, however, were modified based upon feedback from users of the SIS-A, changing from time-based (how often are supports provided) to response items to items that range from 'negligible' to 'always.' The SIS-C was normed with six cohorts of children who were diagnosed by schools with intellectual disability across multiple levels of cognitive impairment. We presumed that support needs would be confounded with age, with younger children having greater support needs than older children., since younger children need more help to perform most activities. So, we adopted a stratified sampling plan, with age cohorts of two years (e.g., 5-6 year olds, 7-8 year olds, etc.). There were over 4,000 children in the norming sample, across ages between 5 and 16 and across mild, moderate, and severe/profound cognitive impairments (THOMPSON et al., 2016a).

We found, in performing the psychometric analyses, that there were age-related differences, as we presumed there would be, with intensity of support needs decreasing across age, though children 5 to 10,11 to 14 , and 15 to 16 tended to have similar mean levels of support needs. For 142 students ages 15-21, we completed both a SIS-A and a SIS-C to compare the relationships among the two measures, and found strong correlations across the SIS-A and SIS-C measures. We examined the reliability and validity of the SIS$\mathrm{C}$ in subset of the norming sample who were identified with intellectual disability only $(\mathrm{n}=$ $1,861)$ or with intellectual disability and autism $(n=2,124)$. There was excellent internal consistency across the domains for children in both groups, and as would be expected, children with a co-occurring diagnosis of autism had consistently higher social support needs that did children with intellectual disability only (THOMPSON et al., 2016a).

Of course, having a statistically reliable and valid measure is not the only important consideration when developing tools to be used by teachers. We surveyed more than 1,500 
http://dx.doi.org/10.5902/1984686X48249

teachers who had conducted more than 10 assessments during the norming process, and found that the feedback was, almost universally positive. Teachers indicated the following about the SIS-C:

\footnotetext{
- It's a more authentic assessment than other assessments because it is not just looking at academic performance. It is looking at the child's total performance.

- It's easy to say what students can't do. The SIS-C helps you know what they can do with support.

- Helps to suggest where to go next in planning activities with a student.

- Good for communication with transitions to new teachers and to new schools.

- With the SIS-C, we are not just looking at what students can't do. Because we are looking at supports, we are not looking at what is 'good/not good' about what a student does. Instead, we are looking at what we can do to help support them.

- Achievement scores provide a snapshot of what a child has learned, but the SIS-C provides a profile of a child in all the major areas of life (THOMPSON et al., 2016, p. 15).
}

Finally, we are currently engaged in a large grant to develop instructional materials and supports for teachers to use to take information generated by the SIS-C to identify supports and create support plans. This support needs assessment and planning process involves teacher observations, the administration of the SIS-C, a problem-solving process to identify supports and prioritize needs. The problem-solving process includes consideration of:

1. What portions of the child's school day do you feel he/she has the greatest level of participation/engagement with activities associated with the General Education Curriculum?

2. What portions of the child's school day do you feel he/she has the least level of participation/engagement with activities associated with the General Education Curriculum?

3. Are there ways to support the child that are being used in \#1 (above) that could be applied to \#2 (above)?

4. Are there certain activities or times of the day that you feel the child is "undersupported"? These are times and activities where the child could participate more fully and be more engaged if additional support was provided.

5. Are there certain activities or times of the day that you feel the child is "oversupported" or perhaps is receiving the wrong kinds of support? These are times when the support - although well-meaning - is perhaps getting in the way of a child fully participating. 
http://dx.doi.org/10.5902/1984686X48249

\section{Conclusions}

So, let me return to the premise of this article. That is, that the supports paradigm and the SIS tools are critical to moving the field of special education to operationalize personenvironment fit models of disability and strengths-based approaches to disability. Why are the SIS tools, and particularly the SIS-C, important for this? Quite simply, when we understand students by their support needs, we are more inclined to:

a. look for strengths (potentials, contributions to make) that supports can build on,

b. perceive successful participation in a classroom as being the consequence of the classroom's capacity to meet a wide range of student needs, and

c. understand that the primary charge of educators involves problem solving to identify and arrange supports (instruction is a support strategy).

The implementation of a supports paradigm, and the measurement of support needs, to an education context is in its early stages. However, there is every reason to believe that this approach will, along with efforts to promote self-determination and other interventions that operationalize a person-environment fit model of disability, enable us to achieve the vision for full inclusion, participation, dignity, respect, and value proposed by the CRPD.

\section{References}

ALMEIDA, Maria Amelia, BOUERI, Iasmin Zanchi; POSTALLI, Lidia Maria Marson. A Escala de Intensidade de Suporte-SIS no Brasil. Journal of Research in Special Educational Needs, vol. 16, pp. 60-64. 2016.

BUNTINX, Wil H. E. Understanding disability: A strengths-based approach. In Michael Lee Wehmeyer (Ed.), The Oxford handbook of positive psychology and disability (pp. 7-18). Oxford, UK: Oxford University Press. 2013.

COMMITTEE ON THE RIGHTS OF PERSONS WITH DISABILITIES. General comment No. 4. 2016. Disponível em: https://www.un.org/development/desa/disabilities/convention-on-therights-of-persons-with-disabilities/article-24-education.html. Acesso em 05 Ago. 2020.

EVANS, Dave. The Internet of Things: How the Next Evolution of the Internet Is Changing Everything. 2011. San Jose, CA: Cisco Internet Business Solutions Group (IBSG). Disponível em: https://www.cisco.com/c/dam/en_us/about/ac79/docs/innov/loT_IBSG_0411FINAL.pdf. Acesso em: 05 Ago. 2020.

LUCKASSON, Ruth. et al. Mental retardation: Definition, classification, and systems of supports (10th ed.). Washington, DC, US: American Association on Mental Retardation. 2002. 
ORKWIS, Raymond; MCLANE, Kathleen. A curriculum every student can use: Design principles for student access. ERIC/OSEP Topical Brief. Reston, VA: Council for Exceptional Children. 1998.

ROSE; David H. et al. Teaching every student in the digital age: Universal Design for Learning. Alexandria, VA: ASCD. 2002.

SHOGREN, Karrie A. et al. Effect of intervention with the Self-Determined Learning Model of Instruction on access and goal attainment. Remedial and Special Education, 33(5), 320-330. 2012.

SHOGREN, Karrie A. et al. Relationships between self-determination and postschool outcomes for youth with disabilities. Journal of Special Education, 48(4), 256-267. 2015.

SHOGREN, Karrie A.; WEHMEYER, Michael Lee; LANE, Kathleen L. Embedding interventions to promote self-determination within multi-tiered systems of supports. Exceptionality, 24(4), 213-244. 2016.

SMITH, J. David; WEHMEYER, Michael Lee. Good blood, bad blood: science, nature and the myth of the Kallikaks. Washington DC: American Association on Intellectual and Developmental Disabilities. 2012.

THOMPSON, James R. et al. Supports Intensity Scale-Children's Version: user's Manual. Washington, D.C., American Association on Intellectual and Developmental Disabilities. 2016a.

THOMPSON, James R. et al. Person-centered planning with the Supports Intensity Sclae-Adult Version: a Guide for Planning Teams. Washington, DC: American Association on Intellectual and Developmental Disabilities. $2016 \mathrm{~b}$.

THOMPSON, James R. et al. Conceptualizing supports and the support needs of people with intellectual disability. Intellectual and Developmental Disabilities, 47, 135-146. 2009.

THOMPSON, James R. et al. Supports Intensity Scale -Adult Version: users manual. Washington, DC: American Association on Intellectual and Developmental Disabilities. 2015.

THOMPSON, James R. et al. Supports Intensity Scale: standardization and users manual. Washington, DC: American Association on Mental Retardation. 2004.

THOMPSON, James R. et al. Supports Intensity Scale-Adult Version Annual Review Protocol. Washington DC: American Association on Intellectual and Developmental Disabilities. 2017.

THOMPSON, James R., WEHMEYER, Michael Lee; HUGHES, Carolyn. Mind the gap! Implications of person-environment fit models of intellectual disability for students, educators, and schools. Exceptionality, 18, 168-181. 2010. 
WEHMEYER, Michael Lee et al. Establishing a causal relationship between interventions to promote self-determination and enhanced student self-determination. Journal of Special Education, 46(4), 195 - 210. 2012a.

WEHMEYER, Michael Lee et al. Support needs of adults with intellectual disability across domains: The role of technology. Journal of Special Education Technology, 27(2), 1122. $2012 b$.

WEHMEYER, Michael Lee. The story of intellectual disability: an evolution of meaning, understanding, and public perception. Baltimore: Paul H. Brookes. 2013a.

WEHMEYER, Michael Lee. Oxford handbook of positive psychology and disability. Oxford, UK: Oxford University Press. 2013b.

WEHMEYER, Michael Lee. Strength-based approaches to educating all learners with disabilities: beyond special education. New York: Teachers College Press. 2019.

WEHMEYER, Michael Lee; ZHAO, Yong. Teaching students to become selfdetermined learners. Alexandria, VA: ASCD. 2020.

ZHAO, Yong. World class learners: Educating creative and entrepreneurial students. Thousand Oaks, CA: Corwin Press. 2012.

\section{Correspondence}

Michael Wehmeyer - Joseph R. Pearson Hall, 518, University of Kansas,1122 West Campus Rd, Lawrence, Kansas - United States of America

CEP: $66045-3101$

This work is licensed under a Creative Commons Attribution-NonCommercial 4.0 International (CC BY-NC 4.0) 